\title{
TRANSIENT GENE EXPRESSION IN ELECTROPORATED INTACT TISSUES OF Stylosanthes guianensis (AUBL.) SW. ${ }^{1}$
}

\author{
Vera Maria Quecini²; Maria Lúcia Carneiro Vieira ${ }^{3 *}$ \\ ${ }_{3}^{2}$ Graduate Student in Genetics and Plant Breeding - USP/ESALQ. \\ ${ }^{3}$ Lab. de Biologia Celular e Molecular de Plantas, Depto. de Genética - USP/ESALQ, C.P. 83 - CEP: $1340-970$ - \\ Piracicaba, SP. \\ ${ }^{*}$ Corresponding author <mlcvieir@carpa.ciagri.usp.br>
}

\begin{abstract}
Genetic transformation though protoplast electroporation has been established for commercially important plant species. In this work, explant sources, electric field strengths, electroporation buffers, DNA forms and osmotic pretreatment were assayed in order to optimize transient reporter gene expression in electroporated tissues of Stylosanthes guianensis, a tropical forage legume. Higher transformation rates were obtained employing cotyledonary explants and an electric field strength of $250 \mathrm{~V} \mathrm{~cm}^{-1}$. Linear plasmid DNA, chloride-free electroporation buffer and osmotic pretreatment with $1.6 \mathrm{~mol} \mathrm{~L}^{-1}$ mannitol also improved transient transformation but non-significantly. Transgene specific PCR amplification was employed to prove the transformed status of the tissues.

Key words: GUS expression, direct DNA transfer, plant transformation, forage legume

\section{EXPRESSÃO TRANSIENTE EM TECIDOS INTACTOS DE Stylosanthes guianensis (AUBL.) SW. VIA ELETROPORAÇÃO}

\begin{abstract}
RESUMO: A transformação genética através da eletroporação de protoplastos foi estabelecida para espécies vegetais comercialmente importantes. Neste trabalho, fontes de explante, intensidades de campo elétrico, soluções de eletroporação, configuração da molécula de DNA e pré-tratamentos osmóticos foram avaliados para otimizar a expressão transiente do gene repórter em tecidos eletroporados de Stylosanthes guianensis, uma leguminosa forrageira tropical. Taxas elevadas de transformação foram obtidas empregando-se explantes cotiledonares e $250 \mathrm{~V} \mathrm{~cm}^{-1}$ de intensidade de campo elétrico. DNA plasmidial linear, solução de eletroporação livre de cloro e pré-tratamento osmótico com 1,6 mol L-1 de manitol favorecerem a expressão transiente do gene repórter, porém não significativamente. A amplificação por PCR específica do transgene foi usada para demonstrar a ocorrência de transformação nos tecidos.

Palavras-chave: expressão de GUS, transferência direta de DNA, transformação de plantas, leguminosa forrageira
\end{abstract}

\section{INTRODUCTION}

Genetic transformation through protoplast electroporation has been established for commercially important plant species, such as Brassica napus (Guerche et al., 1987), maize (Rhodes et al., 1988) and rice (Shimamoto et al., 1989), but requires (i) an effective regeneration protocol from protoplast to fertile nonchimerical transgenic plants; (ii) development of genotype-specific regeneration protocols; (iii) long periods of in vitro cultivation which may induce genetic and epigenetic alterations; (iv) intense and expertise work.

The intact cell wall of bacteria and eukaryotic cells is known to be DNA-permeable to variable extents (Neumann et al., 1996; Lin et al., 1997; Shimogawara et al., 1998) thus, selective permeability lies on the cellular membrane. Electric pulses elevate the transmembrane potential promoting pore formation due to increased dipole moment of the hydrophilic lipid heads (Neumann et al., 1982; Kinosita \& Tsong, 1977). The effects of an electric field on cell walls are still unknown although transgene delivery and expression have been described for goat's rue embryos (Collen \& Jarl, 1999), intact cells of maize (Songstad et al., 1993; Sabri et al., 1996), common bean, cowpea, and other grain legumes (Akella \& Lurquin, 1993; Dillen et al., 1995), rice and wheat (Dekeyser et al., 1990; Xu \& Li, 1994), alfalfa (Senaratna et al., 1991) and sugar beet (Lindsey \& Jones, 1987).

DNA introduction into organized tissues is a promising means to avoid the forementioned constraints of protoplast electroporation and easily obtain wholly transformed plants (Lin et al., 1997).

Genetic transformation of Stylosanthes guianensis (Aubl.) Sw., a tropical forage legume, has been achieved with Agrobacterium infection, but at low efficiency (Wordragen \& Dons, 1992; Sarria et al., 1994). Although being considered one of the less recalcitrant genus of legume to in vitro culture (Vieira et al., 1990), direct gene transfer has never been employed in Stylosanthes. Calli can be obtained from various explant 
sources, and they can further be induced to plant regeneration via organogenesis (Dornelas et al., 1992), thus suggesting that direct tissue electroporation could be effective to generate transformants.

We have evaluated the factors affecting plasmid DNA introduction and expression into organized tissue of Stylosanthes guianensis (Aubl.) Sw. and provided discussions about the effects of electric pulses on intact plant cell walls. To our knowledge, this is the first report of direct gene transference to this species.

\section{MATERIAL AND METHODS}

\section{Plant material and tissue cultures}

Seeds of Stylosanthes guianensis cv. Mineirão were in vitro germinated on half-strength MS medium (Murashige \& Skoog, 1962) as described by Dornelas et al. (1992), at a density of 15 seeds per flask. Hypocotyls and fully expanded cotyledons were excised from 7 to 8 day old seedlings and completely developed leaves from 14 to 15 day old ones. Explants were cut into segments of approximately $2 \mathrm{~mm}^{2}$.

After electroporation, the explants were thoroughly washed with autoclaved water, dried on sterile filter paper and placed on MS3 (MS salts, 3\% sucrose, $0.18 \%$ Phytagel) during two days for the $\beta$-glucuronidase (GUS) test (Jefferson et al., 1987) or 14 days for polymerase chain reaction (PCR) analysis. The longer period of in vitro culture of the explants destined to PCR analysis was employed in order to rule out the possibility of amplification of non-transformed, surface contaminant DNA.

Cultures were maintained under $25^{\circ} \mathrm{C}$ and $16 \mathrm{~h}$ light regime $\left(65 \mu \mathrm{E} \mathrm{m}^{-2} \mathrm{~s}^{-1}\right)$ provided by cool white fluorescent tubes (Sylvannia, $85 \mathrm{~W}$ ).

\section{Plasmid}

Transformation vector pCambia 1301 (CAMBIA GPO Box 3200, Canberra ACT 2601, Australia) carrying $\beta$-glucuronidase (GUS) - uidA, driven by $35 \mathrm{~S}$ promoter from cauliflower mosaic virus (CaMV) (Figure 1). The presence of a catalase intron into the coding sequence of uidA rules out the possibility of reporter gene expression in transformed endophytic microorganisms. The plasmid was transformed to E. coli DH5 $\alpha$ (Hanahan, 1983) and isolated by alkaline lysis (Sambrook et al., 1989). Supercoiled or plasmid DNA linearized through digestion with EcoRI (GIBCO BRL) was employed in transformation experiments.

\section{Pre-pulse treatments}

Hypocotyls $(H)$, cotyledonary $(C)$ and leaf $(L)$ sections were presoaked in $5 \mathrm{~mL}$ of electroporation buffer supplemented with $0,0.2,0.8$ or $1.6 \mathrm{~mol} \mathrm{~L}^{-1}$ mannitol for $20 \mathrm{~min}$ at $0^{\circ} \mathrm{C}$. Prior to pulsing, $10 \mu \mathrm{g}$ of supercoiled or linear plasmid DNA were added to each $800 \mu \mathrm{L}$ mixture of electroporation buffer and explants. The cuvettes were kept on ice for $10 \mathrm{~min}$ before pulsing.

\section{Electroporation conditions}

Commercial Bio $\operatorname{Rad}^{\circledast}$ Gene Pulser II with Capacitance Extender device was employed to deliver 50 to $250 \mathrm{~V}$. $\mathrm{cm}^{-1}$ electric field, by discharging a $900 \mu \mathrm{F}$ capacitor to $0.4 \mathrm{~cm}$ electrode-gap cuvettes $(800 \mu \mathrm{L}$ volume) containing 10 explants in electroporation buffer I (Fromm et al., 1987), II (Tada et al., 1990) or III (Walbot, 1993).

Sample resistances were $20 \Omega$ (buffer I and III) and $50 \Omega$ (buffer II) as determined by the device measurements. The time, expressed as pulse decay constant, established by internal settings of the apparatus was $\tau=R C$.

\section{Histochemical GUS assays}

Explants were histochemically analyzed for $\beta$ glucuronidase activity as described by Jefferson et al. (1987). Electroporated tissues were longitudinally sliced and vacuum-infiltrated for 5 min with staining buffer containing the chromogenic substrate, 5-bromo-4-chloro3-indolyl glucuronide (X-Gluc) (McCabe et al., 1988) with addition of $20 \%$ methanol in order to suppress endogenous $\beta$-glucuronidase activity (Kosugi et al., 1990). After 24 -hour incubation at $37^{\circ} \mathrm{C}$, tissue pigments were removed by successive washes with $80 \%$ ethanol, and the explants were observed under the stereomicroscope.

\section{PCR analysis}

After 14 days of culture in MS3, genomic DNA was isolated as described by Edwards et al. (1991) from randomly chosen samples of electroporated explants and non-electroporated controls.

Each $25 \mu \mathrm{L}$ reaction mixture contained $20 \mathrm{ng}$ of genomic DNA, $10 \mathrm{mM}$ TRIS-HCl (pH 8.4), $50 \mathrm{mM} \mathrm{KCl}$, $2.0 \mathrm{mM} \mathrm{MgCl}, 160 \mu \mathrm{M}$ of each dNTP, $1.0 \mathrm{U}$ of Taq polymerase (GIBCO BRL) and 200nM of each uidA specific primer (gus 1 - CCT GTA GAA ACC CCA CAA CG and gus 2 c - TGC AGC GCT ACC TAA GGC CG) (Figure 1), which provide an amplification product of $795 \mathrm{bp}$. The mixture was overlaid with sterile mineral oil and submitted to denaturation $\left(2 \mathrm{~min}\right.$ at $95^{\circ} \mathrm{C}$ ) followed by 25 cycles of amplification $\left(1 \mathrm{~min}\right.$ at $94^{\circ} \mathrm{C}$, $1 \mathrm{~min}$ at $45^{\circ} \mathrm{C}$ and $1.5 \mathrm{~min}$ at $72^{\circ} \mathrm{C}$ ) and a final extension $\left(7 \mathrm{~min}\right.$ at $72^{\circ} \mathrm{C}$ ) in thermal cycler (Perkin Elmer Cetus).

\section{Statistical procedures and data analysis}

A cuvette containing ten explants (approximately $2 \mathrm{~mm}^{2}$ ) was considered a replicate, and three replicates were evaluated for both GUS and PCR analysis in a randomized design experiment.

All tested variables, i.e. explant type, electric field strength, osmotic treatment, DNA form and buffer types, were independently assayed and compared to reference conditions. Reference conditions were: buffer I (Fromm et al., 1987), $10 \mu \mathrm{g}$ of non-linearized plasmid DNA, no osmotic treatment previous to pulse and $100 \mathrm{~V} \mathrm{~cm}^{-1}$ 
discharged by $900 \mu \mathrm{F}$ capacitor (720 kJ) to cotyledonderived explants.

GUS stained areas were visually evaluated and attributes were given from 0 to 5 according to their size, intensity and frequency per explant. Data are the mean number of three independent replicates (30 explants) \pm se (standard error). Mean comparisons were performed employing the Tukey test ( $1 \%$ and $5 \%$ probability).

\section{RESULTS AND DISCUSSION}

\section{Effect of explant type on transgene expression}

Cotyledons showed the highest levels of GUS expression (Figures $2 \mathrm{~A}$ and $3 \mathrm{~A}$ ) independent of the buffer employed, DNA form, osmotic treatment and electric field strength, followed by hypocotyl-derived explants (Figures $2 \mathrm{~B}$ and $3 \mathrm{~A})$. Leaves showed the lowest transformation rates (Figures 2C and 3A). Songstad et al. (1993) also reported low levels of expression in electroporated leaves of maize embryos. Qualitatively, as evaluated by the arbitrary expression scale, leaves also showed poor transformation rates (Figure 3B).

Pools of DNA from 20 randomly chosen explants of all transformed tissues showed PCR amplification of the transgene after 14 days of in vitro culture from two independent experiments (Figure 4), confirming their transformed status.

As reported for electroporated tissues of common bean (Dillen et al., 1995), maize (Songstad et al., 1993) cowpea (Akella \& Lurquin, 1993) and rice (Dekeyser et al., 1990), GUS expression in Stylosanthes (Figures 2A to $2 \mathrm{C}$ ) appeared as blue-stained areas, without clear definition of the cells which were actually expressing the reporter gene.

\section{Optimizing field strength to foreign DNA deliver}

Fixed discharge capacity was employed $(\mathrm{C}=900 \mu \mathrm{F})$ in an $\mathrm{RC}$ circuit, thus the energy input was correlated to the applied voltage $\left(E=1 / 2 \mathrm{CV}^{2}\right)$ and ranged from $180 \mathrm{~kJ}$ (at $50 \mathrm{~V} \mathrm{~cm}^{-1}$ ) to $8820 \mathrm{~kJ}$ (at 350 $\left.\mathrm{V} \mathrm{cm}^{-1}\right)$. The strength of the electric field promotes pore formation in cellular membranes (Kinosita \& Tsong 1977; Neumann et al., 1982), alters the viscosity of homogalacturan gel-like structure (Zablackis et al., 1995) and affects ionic interactions of positively-charged lysine and histidine residues from extensins to negatively-charged uronic acid from pectin (Showalter, 1993; Reiter, 1998) allowing macromolecular migration across these structures.

Highest transformation levels were observed employing electric fields ranging from 100 to $250 \mathrm{~V} \mathrm{~cm}$ (Figure 5A). Discharges of $350 \mathrm{~V} \mathrm{~cm}^{-1}$ caused tissue injuries and reduced GUS expression levels, even when compared to low energy electric fields $(50 \mathrm{~V} \mathrm{~cm}$ ) (Figure $5 A)$.

Cotyledon and hypocotyl-derived tissues showed approximately the same patterns of GUS expression, with the highest values ranging from 150 to $250 \mathrm{~V} \mathrm{~cm}^{-1}$ (Figure 5B), which are similar to those reported by Dillen et al. (1995) for bean embryonic axes. No GUS expression was observed with electric field intensities lower than $50 \mathrm{~V} \mathrm{~cm}^{-1}$ or higher than 350 $\mathrm{V} \mathrm{cm}{ }^{-1}$.

\section{Effect of electroporation buffer on DNA introduction}

No statistical differences $(P<0.05)$ were observed concerning explants electroporated with buffer I, II and III. Tada et al. (1990) reported increased efficiency employing electroporation buffer lacking chloride in the transformation of rice protoplasts, but it is very likely that the effect of reactive oxygen derived from chloride reaction is not so drastic in intact cell walls. However, qualitative analysis of GUS expression showed that chloride-free buffers II and III had greater number of explants included in expression level 4 and 5 of the arbitrary scale in electroporated Stylosanthes cotyledons (Figure 6).

\section{Influence of DNA configuration on gene expression}

Linear DNA was most effectively introduced into whole tissues of Stylosanthes (Figure 7), as described for other Fabaceae (Akella \& Lurquin, 1993; Dillen et al., 1995). Higher efficiency of transformation employing linearized plasmid DNA has been reported for bacteria (Rittich \& Spanova, 1996), yeast and filamentous fungi (Kwon-Chung et al., 1998), plant protoplasts (Lin et al., 1997) and intact tissues (Lin et al., 1997; Sabri et al., 1996; Saunders et al., 1995; Dillen et al., 1995; Akella \& Lurquin, 1993).

The transient nature of membrane pores and structural alterations of the cell wall induced by electric fields imposes conformational restrictions to the macromolecules to be introduced (Neumann et al., 1982).

\section{Influence of the osmoticum pretreatment on transient GUS expression}

No statistically significant enhancement $(P<$ $0.05)$ was observed in the frequency of gene expression (Figure 8A). However, $0.8 \mathrm{~mol} \mathrm{~L}^{-1}$ and 1.6 mol $\mathrm{L}^{-1}$ mannitol increased the number and intensity of blue spots, as evaluated by the arbitrary scale (Figure $8 \mathrm{~B})$. There was positive correlation $\left(r^{2}=0.9129\right)$ between the osmotic concentration $(x)$ and the number of explants expressing GUS (y), described as $y=8.82 x+37.35$.

Osmotic treatment of the target tissue has been reported to increase transformation rates from 7- to 10-fold in microorganisms (Armaleo et al., 1990; Shark et al., 1991) and plant cells (Russell et al., 1992; Vain et al., 1993). The increased distance between the cell wall and cytoplasm in plasmolyzed cells makes them less susceptible to organelle damage and cytoplasm loss when immersed in an electric field. 


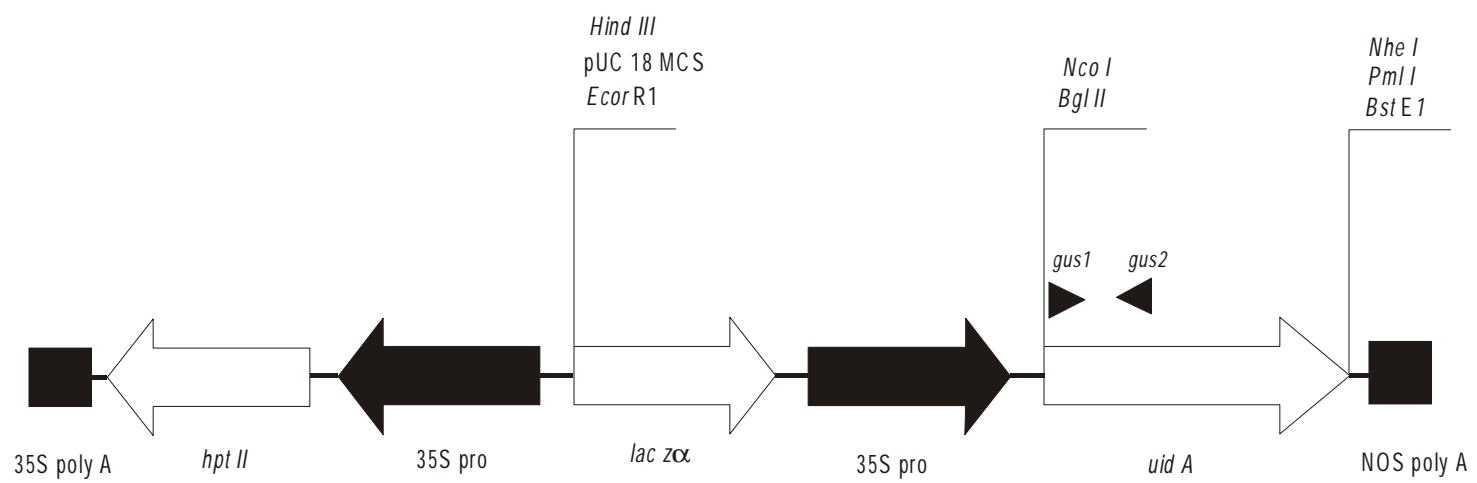

Figure 1 - Transformation vector pCambia 1301 expression cassette. PCR primers are indicated by (gus1) and (gus2). Arrows indicate cloning direction. Regulatory sequences (polyadenilation signals - poly A and promoters - pro) are shown as filled segments and coding sequences as unfilled ones. MCS = multicloning site, NOS = nopaline synthase, lacz $\alpha=\alpha$ subunit of bacterial lactase.
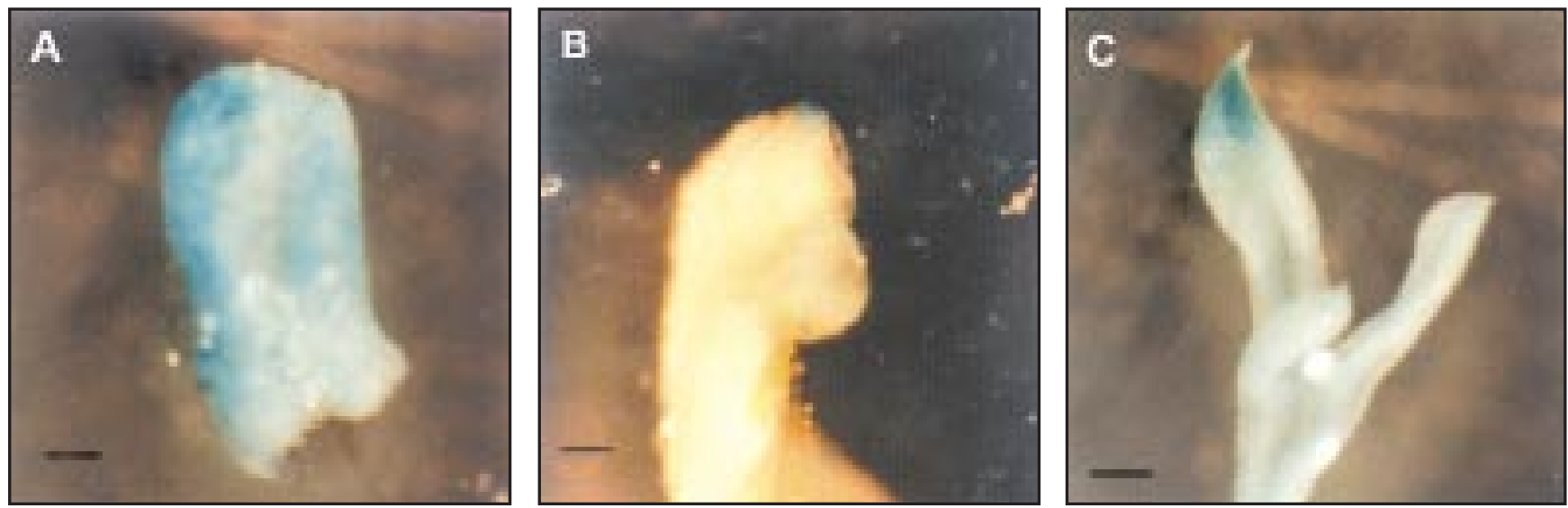

Figure 2 - GUS expression in electroporated Stylosanthes guianensis intact tissues. (A) cotyledon, (B) hypocotyl, (C) leaf. Bar=2 mm.
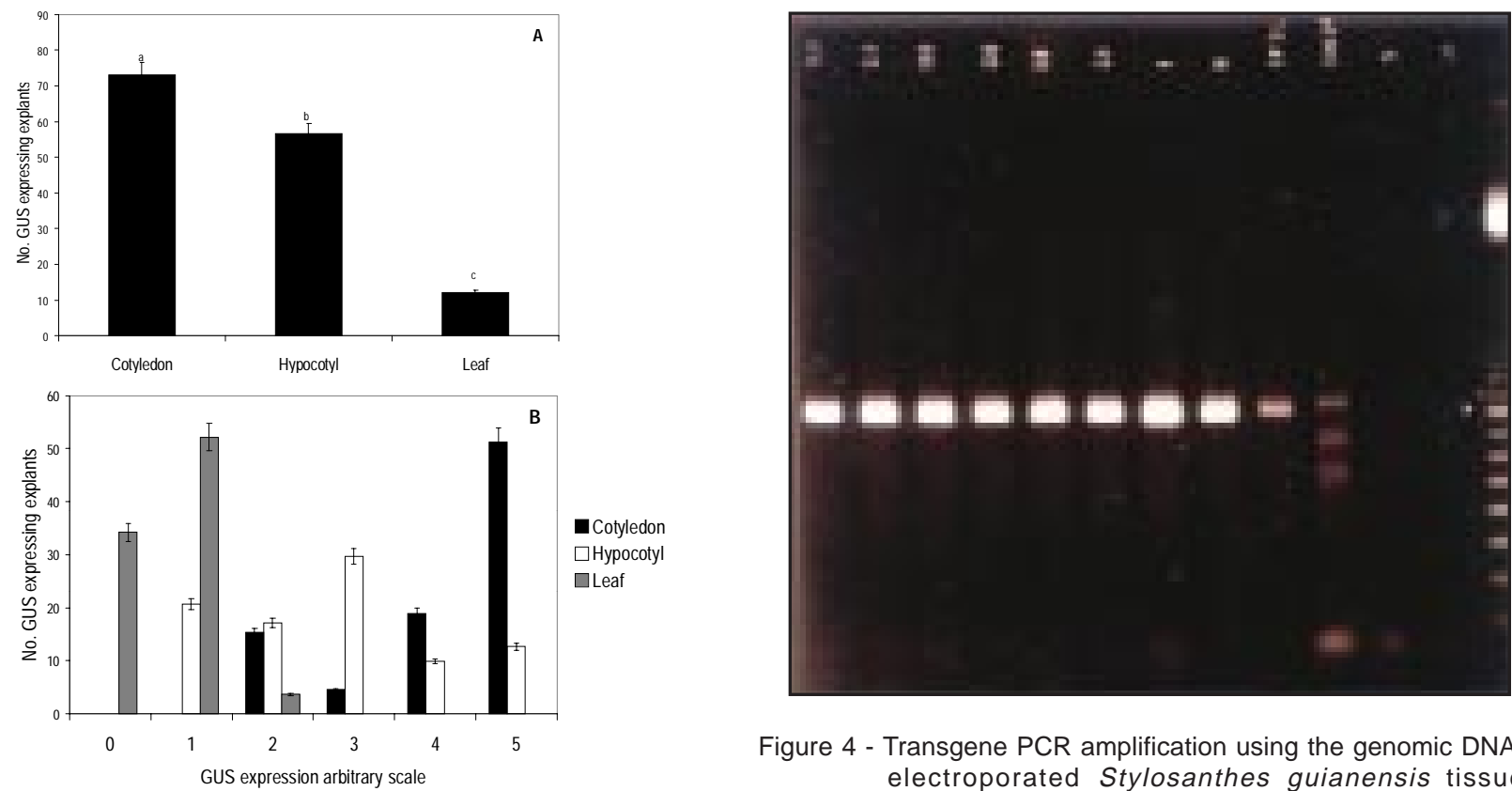

Figure 4 - Transgene PCR amplification using the genomic DNA of electroporated Stylosanthes guianensis tissues. Cotyledon (C), hypocotyl $(H)$ and leaf $(F)$ DNA from two independent experiments (1 and 2). Transgenic $S$. guianensis plants (1, 8 and 7/2.41, Quecini, 1999) and plasmid pCambia 1301 DNA were employed as positive controls; non-electroporated buffer-incubated tissue (S), and PCR mix without template DNA (C) were employed as negative controls. Molecular marker: 100 bp DNA ladder (Pharmacia).

Scientia Agricola, v.58, n.4, p.759-765, out./dez. 2001 

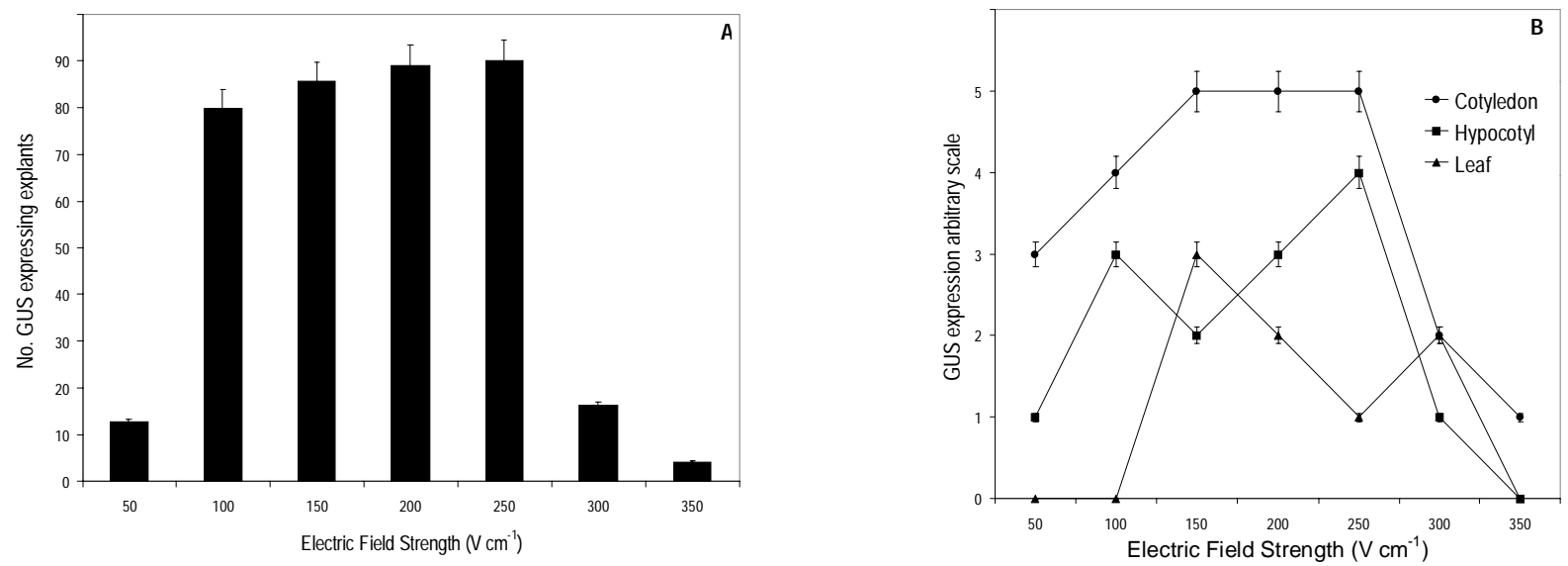

Figure 5 - Effect of electric field strength on GUS expression in electroporated tissues of S. guianensis. (A) Number of explants expressing GUS. (B) Classification of GUS positive explants electroporated with different field strengths according to the arbitrary scale. Electroporation conditions: cotyledons, $900 \mu \mathrm{F}, 20 \Omega$, buffer I, $10 \mu \mathrm{g}$ of supercoiled DNA, absence of osmotic treatment. Bars indicate se.

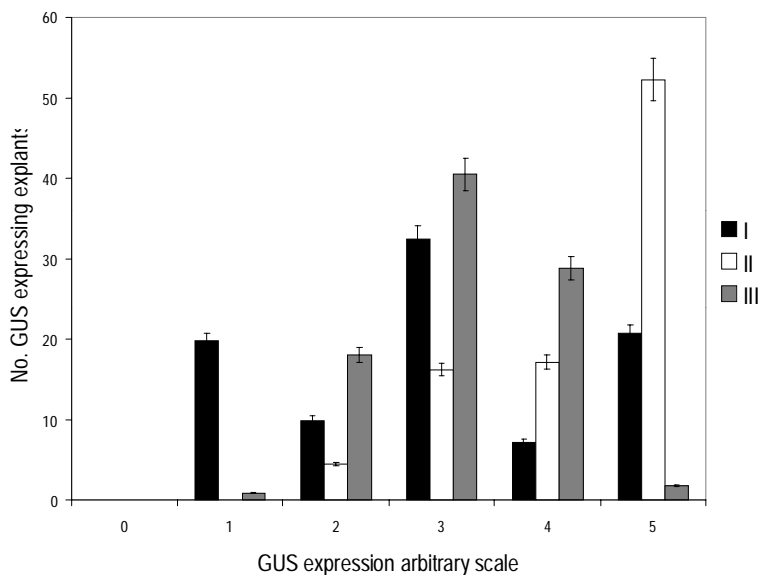

Figure 6 - Effect of electroporation buffer on GUS expression in electroporated tissues of $S$. guianensis. GUS positive explants electroporated with different buffers were classified according to the arbitrary scale. Electroporation conditions: cotyledons, $900 \mu \mathrm{F}, 20 \Omega$ (buffer I and III) and $50 \Omega$ (buffer II), $100 \mathrm{~V} \mathrm{~cm}^{-1}, 10 \mathrm{mg}$ of supercoiled DNA, absence of osmotic treatment. Bars indicate se.

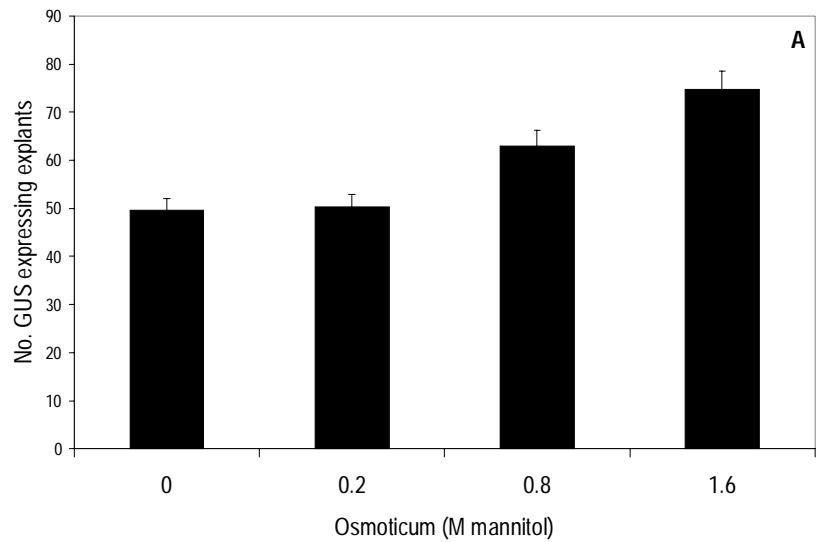

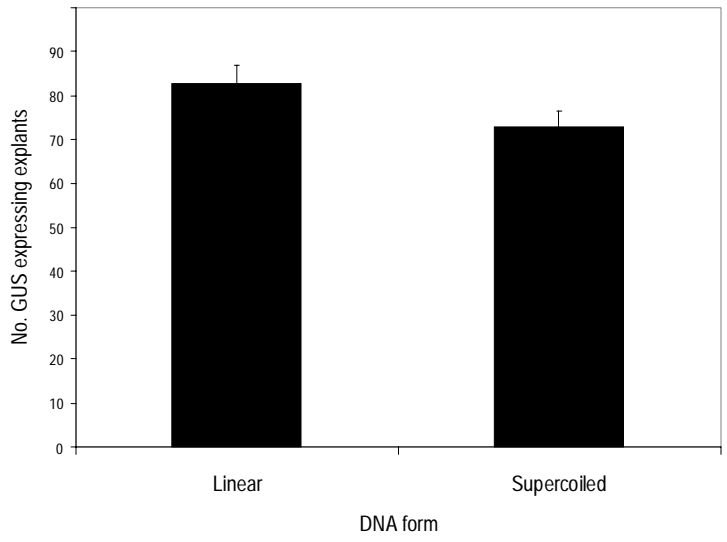

Figure 7 - Effect of the DNA form on GUS expression in electroporated tissues of $S$. guianensis. Electroporation conditions: cotyledons, $900 \mu \mathrm{F}, 20 \Omega, 100 \mathrm{~V} \mathrm{~cm}^{-1}, 10 \mu \mathrm{g}$ of DNA, absence of osmotic treatment. Bars indicate se.

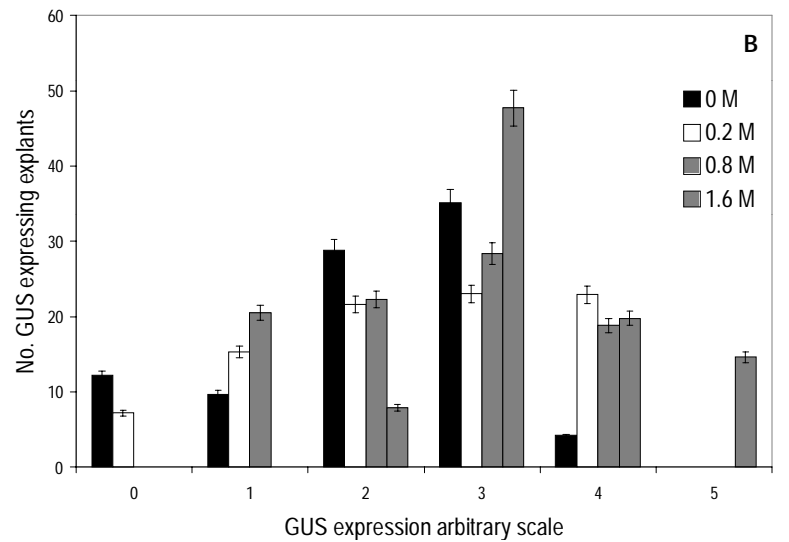

Figure 8 - Effect of osmotic pretreatment on GUS expression in electroporated tissues of S. guianensis. (A) Number of explants expressing GUS. (B) Classification of GUS positive electroporated explants pretreated with different concentration of mannitol according to the arbitrary scale. Electroporation conditions: cotyledons, $900 \mu \mathrm{F}, 100 \mathrm{~V} \mathrm{~cm}^{-1}, 20 \Omega$, buffer I, $10 \mu \mathrm{g}$ of supercoiled DNA. Bars indicate se. 


\section{CONCLUSIONS}

Intact tissues of Stylosanthes guianensis (Aubl.) Sw. can be transformed with plasmid DNA after electroporation. Transient reporter gene expression is dependent upon biological and physical parameters. The explant source and energy input are the most important. Higher rates of transformation were obtained employing cotyledonary explants and electric fields ranging from 100 to $250 \mathrm{~V} \mathrm{~cm}^{-1}$. Electroporation buffer, DNA form and osmotic pretreatment were not critical to transient transformation efficiency. To our knowledge, this is the first report on direct gene transfer in Stylosanthes, demonstrating the applicability of intact tissue electroporation to genetic manipulation of the genus.

Due to its importance for Latin American countries, the development of Stylosanthes biotechnological procedures must respond to increasing demands in terms of sustainable use of plant genetic resources as basic inputs for the future agriculture (see Izquierdo \& de la Riva, 2000).

\section{ACKNOWLEDGEMENTS}

To Dr. C. Karia (CPAC / EMBRAPA) for kindly providing Stylosanthes guianensis cv. Mineirão seeds. This research work is supported by Fundação de Amparo à Pesquisa do Estado de São Paulo (FAPESP), Grant No.98/11270-7 to M.L.C.V. We also acknowledge Conselho Nacional de Desenvolvimento Científico e Tecnológico (CNPq) for supplying the doctoral scholarship to V.M.Q.

\section{REFERENCES}

AKELLA, V.; LURQUIN, P.F. Expression in cowpea seedlings of chimeric transgenes after electroporation into seed-derived embryos. Plant Cell Reports, v.12, p.110-117, 1993.

ARMALEO, D.; YE, G-N.; KLEIN, T.M.; SHARK, K.B.; SANFORD, J.C.; JOHNSTON, S.A. Biolistic nuclear transformation of Saccharomyces cerevisiae and other fungi. Current Genetics, v.17, p.97-103, 1990.

COLLEN, A.M.C.; JARL, C.I. Comparison of different methods for plant regeneration of the legume Galega orientalis Lam. (goat's rue). Plant Cell Reports, v.19, p.13-19, 1999.

DEKEYSER, R.A.; CLAES, B.; DE RYCKE, R.M.U.; HABETS, M.E.; VAN MONTAGU, M.C.; CAPLAN, A.B. Transient gene expression in intact and organized rice tissues. Plant Cell, v.2, p.591-602, 1990.

DILLEN, W.; ENGLER, G.; VAN MONTAGU, M.; ANGENON, G. Electroporation-mediated DNA delivery to seedling tissues of Phaseolus vulgaris L. (common bean). Plant Cell Reports, v.15, p.119-124, 1995.

DORNELAS, M.C.; VIEIRA, M.L.C.; APPEZZATO-DA-GLÓRIA, $B$. Histological analysis of organogenesis and somatic embryogenesis induced in immature tissues of Stylosanthes scabra. Annals of Botany, v.70, p.477-482, 1992.

EDWARDS, K.; JOHNSTONE, C.; THOMPSON C. A simple and rapid method for the preparation of plant genomic DNA for PCR analysis. Nucleic Acids Research, v.19, p.1349, 1991.
FROMM, M.; CALLIS, J.; TAYLOR, L.P.; WALBOT, V. Electroporation of DNA and RNA into plant protoplasts. Methods of Enzymology, v.153, p.351-365, 1987.

GUERCHE, P.; CHAVONNIER, M.; JOUANIN, L.; TOURNEUR, C.; PASZKOWSKI, J.; PELLETIER, G. Direct gene transfer by electroporation in Brassica napus. Plant Science, v.52, p.111-116, 1987.

HANAHAN, D. Studies on the transformation of Escherichia coli with plasmids. Journal of Molecular Biology, v.166, p.557580, 1983.

IZQUIERDO, J.; DE LA RIVA, G. A. Plant biotechnology and food security in Latin America and Caribbean. Electronic Journal of Biotechnology, v.15, p.1-13, 2000.

JEFFERSON, R.A.; KAVANAGH, T.A.; BEVAN, M.W. GUS fusion: the $\beta$-glucuronidase as sensitive and versatile gene fusion marker in higher plants. EMBO Journal, v.6, p.3301-3307, 1987.

KINOSITA, K.; TSONG, T.Y. Voltage-induced pore formation and hemolysis of human erythrocytes. Biochemica and Biophysica Acta, v.471, p.227-242, 1977.

KOSUGI, S.; OHASHI, Y.; NAKAJIMA, K.; ARAI, Y. An improved assay for $\beta$-glucuronidase in transformed cells: methanol almost completely suppresses a putative endogenous $\beta$-glucuronidase activity. Plant Science, v.70, p.133-140, 1990.

KWON-CHUNG, K.J.; GOLDMAN, W.E.; KLEIN, B.; SZANISZLA, P.J.; POLONELLI, L.O.; WALSH, T.J. Fate of transforming DNA in pathogenic fungi. Medical Mycology, v.36, p.38-44, 1998.

LIN, C.H.; XIAO, L.; HOU, B.H. Optimization of electroporation conditions for expression of GUS activity in electroporated protoplasts and intact cells. Plant Physiology and Biochemistry, v.35, p.959-968, 1997.

LINDSEY, K.; JONES, M.G.K. The permeability of electroporated cells and protoplasts of sugar beet. Planta, v.172, p.346-355, 1987.

McCABE, D.E.; SWAIN, W.F.; MATINELL, J.B.; CHRISTOU, P. Stable transformation of soybean (Glycine max) by particle acceleration. Bio/Technology, v.6, p.923-926, 1988.

MURASHIGE, T.; SKOOG, F. A revised medium for rapid growth and bioassays with tobacco tissue cultures. Physiologia Plantarum, v.15, p.473-497, 1962.

NEUMANN, E.; KAKORIN, S.; TSONEVA, I. Calcium-mediated DNA adsorption to yeast cells and kinetics of cell transformation by electroporation. Biophysical Journal, v.71, p.868-877, 1996.

NEUMANN, E.; SCHÄEFER-RIDDER, M.; WANG, M.; HOFSCHNEIDER, P.H. Gene transfer into mouse lyoma cells by electroporation in high electric fields. EMBO Journal, v.1, p.841-845, 1982.

REITER, W-D. The molecular analysis of cell wall components. Trends in Plant Science, v.3, p.27-32, 1998.

RITTICH, B.; SPANOVA, A. Electrotransformation of bacteria by plasmid DNAs: statistical evaluation of a model quantitatively describing the relationship between the number of electrotransformants and DNA concentration. Bioelectrochemistry and Bioenergetics, v.40, p.233-238, 1996.

RHODES, C.A.; PIERCE, D.A.; METTLER, I.J.; MASCARENHAS, D.; DETMER, J.J. Genetically transformed maize plants from protoplasts. Science, v.240, p.204-207, 1988.

RUSSELL, J.A.; ROY, M.K.; SANFORD, J.C. Major improvements in biolistic transformation of suspension-cultured tobacco cells. In Vitro Cellular and Developmental Biology, v.28, p.97105, 1992.

SABRI, N.; PELISSIER, B.; TEISSIE, J. Transient and stable electrotransformation of intact black Mexican sweet maize cells are obtained after preplasmolysis. Plant Cell Reports, v.15, p.924-928, 1996. 
SAMBROOK, J.; FRITSCH, E.F.; MANIATIS, T. Molecular cloning: a laboratory manual. 2.ed. New York: Cold Spring Harbor Laboratory Press, 1989. v.1.

SARRIA, R.; CALDERÓN, A.; THRO, A.M.; TORRES, E.; MAYER, J.E.; ROCA, W.M. Agrobacterium-mediated transformation of Stylosanthes guianensis and production of transgenic plants. Plant Science, v.96, p.119-127, 1994.

SAUNDERS, J.A.; LIN, C.H.; HOU, B.H. Rapid optimization of electroporation conditions for plant cells, protoplasts and pollen. Molecular Biotechnology, v.3, p.181-190, 1995.

SENARATNA, T.; MCKERSIE, B.D.; KASHA, K.J.; PROCUNIER, J.D. Direct DNA uptake during the imbibition of cells. Plant Science, v.79, p.223-228, 1991.

SHARK, K.B.; SMITH, F.D.; HARPENDING, P.R.; RASMUSSEN, J.L.; SANFORD, J.C. Biolistic transformation of a prokaryote, Bacillus megaterium. Applied and Environmental Microbiology, v.57, p.480-485, 1991.

SHIMAMOTO, K.; TERADA, R.; IZAWADA, T.; FUJIMOTO, $\mathrm{H}$. Fertile transgenic rice plants regenerated from transformed protoplasts. Nature, v.338, p.274-276, 1989.

SHIMOGAWARA, K.; FUJIWARA, S.; GROSSMAN, A. High-efficiency transformation of Chlamydomonas reinhardtii by electroporation. Genetics, v.148, p.1821-1828, 1998.

SHOWALTER, A.M. Structure and function of plant cell wall proteins. Plant Cell, v.5, p.9-23, 1993.

SONGSTAD, D.D.; HALAKA, F.G.; DEBOER, D.L.; ARMSTRONG, C.L.; HINCHEE M.A.W.; FORD-SANTINO, C.G.; BROWN, S.M.; FROMM, M.E.; HORSCH, R.B. Transient expression of GUS and anthocyanin constructs in intact maize immature embryos following electroporation. Plant Cell Tissue and Organ Culture, v.33, p.195-201, 1993.
TADA, Y.; SAKAMOTO, M.; FUJIMURA; T. Efficient gene introduction into rice by electroporation and analysis of transgenic plants: use of electroporation buffer lacking chloride ions. Theoretical and Applied Genetics, v.80, p.475-480, 1990.

VAIN, P.; MCMULLEN, M.D.; FINER, J.J. Osmotic treatment enhances particle bombardment-mediated transient and stable transformation of maize. Plant Cell Reports, v.12, p.84-88, 1993.

VIEIRA, M.L.C.; JONES, B.; COCKING, E.C.; DAVEY, M.R. Plant regeneration from protoplasts isolated from seedling cotyledons of Stylosanthes guianensis, S. macrocephala and S. scabra. Plant Cell Reports, v.9, p.289-292, 1990.

WALBOT, V. Gene pulser ${ }^{\circledR}$ electroprotocols. Hercules-CA: BioRad Laboratories, 1993. p.882. (Survey Number, 181)

WORDRAGEN, M.F. van; DONS, H.J.M. Agrobacterium tumefaciens-mediated transformation of recalcitrant crops. Plant Molecular Biology Reporter, v.10, p.12-36, 1962.

$\mathrm{XU}, \mathrm{X}$.; LI, B. Fertile transgenic Indica rice plants obtained by electroporation of the seed embryo cells. Plant Cell Reports, v.13, p.237-242, 1994.

ZABLACKIS, E.; HUANG, J.; MÜLLER, B.; DARVILL, A.G.; ALBERSHEIM, P. Characterization of the cell-wall polysaccharides of Arabidopsis thaliana leaves. Plant Physiology, v.107, p.1129 -1138, 1995.

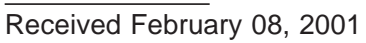

